\title{
ANALISIS NILAI RELIGIUS DALAM NOVEL RANAH 3 WARNA KARYA AHMAD FUADI DAN RRP KELAS XII
}

Wandi Setiawan', $^{1}$ Tanti Agustiani ${ }^{2}$, David Setiadi ${ }^{3}$

wandisetya002@ummi.ac.id; agustianitanti@gmail.com; david156@ummi.ac.id

\section{Universitas Muhammadiyah Sukabumi}

\begin{abstract}
Abstrak. Penelitian ini berupa pemaparan analisis nilai religius dalam novel Ranah 3 Warna Karya Ahmad Fuadi. Berdasarkan data hasil analisis terdapat beberapa indicator mengenai nilai-nilai religus pada novel tersebut. Hasil dari analisis nilai religius kemudian dijadikan sebagai bahan ajar yang berupa Rencana Pelaksanaan Pembelajaran (RPP) pada kelas XII di SMA negeri 1 Cikidang. Tujuan dari penelitian ini bermaksud untuk memudahkan penyampaian materi tentang analisis karya sastra di kelas XII pada SMA Negeri 1 Cikidang.
\end{abstract}

Kata Kunci : Novel, Nilai Religius, Rencana Pembelajaran.

Abstract. This research is in the form of exposure to an analysis of religious values in the novel Ranah 3 Warna Karya Ahmad Fuadi. Based on the data analysis results there are several indicators about the values of religus in the novel. The results of the analysis of religious values are then used as teaching material in the form of a Learning Implementation Plan (RPP) in class XII at SMA Negeri 1 Cikidang. The purpose of this study intends to facilitate the delivery of material about the analysis of literary works in class XII at SMA Negeri 1 Cikidang.

\section{PENDAHULUAN}

Sastra merupakan suatu keindahan, suatu bentuk ekspresi diri manusia. Wellek dan Warren (2016) mengungkapkan bahwa sastra adalah suatu kegiatan kreatif sebuah karya seni dan salah satu batasannya yaitu segala sesuatu yang tertulis atau tercetak. Dengan demikian, sastra adalah suatu bentuk kehidupan manusia yang diungkapkan secara tertulis ataupun lisan dalam sebuah karya sastra yang berfungsi untuk suatu peneladanan yang berasal dari pemikiran, imajinasi, perasaan, dan pengalaman kehidupan sosial manusia.

Sastra merupakan suatu keindahan, suatu bentuk ekspresi diri manusia. Wellek dan Warren (2016) mengungkapkan bahwa sastra adalah suatu kegiatan kreatif sebuah karya seni dan salah satu batasannya yaitu segala sesuatu yang tertulis atau tercetak. Dengan demikian, sastra adalah suatu bentuk kehidupan manusia yang diungkapkan secara tertulis ataupun lisan dalam sebuah karya sastra yang berfungsi untuk suatu peneladanan yang berasal dari pemikiran, imajinasi, perasaan, dan pengalaman kehidupan sosial manusia..
Karya sastra sebagai hasil cipta seseorang yang sarat dengan nilai, nilai keindahan maupun nilai ajaran hidup. Nilai keindahan dalam karya sastra merupakan ciri bahwa karya sastra adalah karya seni. Menurut Sukirno (2013:3) menjelaskan bahwa kreatifitas menuang gagasan secara tertulis atau melahirkan daya cipta berdasarkan pikiran dan perasaan dalam bentuk tulisan atau karangan dalam teks.

Perkembangan sastra Indonesia demikian luas dan pesatnya, dengan beragam genre yaitu ada tiga genre sastra yang mewarnai kesusastraan Indonesia, yaitu puisi, prosa dan drama. Ketiga genre tersebut tidak pernah berhenti diciptakan dan selalu mendapat perhatian dari peminat sastra. Sebagai suatu karya, sastra tidak hanya dinikmati, tetapi untuk dikaji dan diteliti agar kita dapat memahami makna yang tersirat dalam sebuah karya sastra.

Dengan memahami makna yang tersirat dalam sebuah sastra, maka nilai-nilai yang terkandung dalam sebuah sastra tersebut akan dapat kita pahami. Karya sastra terbagi menjadi tiga jenis yaitu puisi,drama, dan prosa.

Dari beberapa genre sastra, jenis sastra yang berisi tentang kisah dan 


\section{ANALISIS NILAI RELIGIUS DALAM NOVEL RANAH 3 WARNA KARYA AHMAD FUADI DAN RRP KELAS XII}

permasalahan-permasalahan

dalam

kehidupan manusia adalah novel. Novel merupakan bagian genre prosa fiksi (fiction) yang mengungkapkan aspekkemanusiaan yang lebih mendalam dan disajikan dengan halus.

Nilai religius merupakan aspek yang ada pada sebuah karya sastra, seperti halnya dalam karya sastra novel. Religius adalah konsep keagamaan yang menyebabkan manusia bersikap sesuai dengan perintah Tuhan-Nya. Novel sebagai bagian dari karya sastra yang mengungkapkan makna kahidupan dari batin seorang pengarang yang mengandung aspek religius mempunyai peranan penting bagi kehidupan manusia. Mangunwijaya (1988:11) mengungkapkan bahwa pada awal mula, segala sastra adalah religius. Oleh karena itu, sastra dapat mempengaruhi sikap dan tingkah laku pembacanya untuk bersikap religius.

Nilai religius adalah perilaku seseorang yang sesuai dengan ajaran agama. (Jauhari,2010:27) Seseorang yang religius dapat diartikan sebagai manusia yang berarti saleh, teliti dan penuh pertimbangan spiritual. Penghayatan yang terus menerus dilakukan oleh manusia, dengan norma yang diyakini melalui perasaan batin yang ada Hubungan dengan Tuhan. Perasaan takut kepada Tuhan, mengakui kebesaran Tuhan, tunduk terhadap Yuhan, taat kepada Tuhan dan menyerahkan diri kepada yang maha kuasa. (Lathief,2008:175; Nova dkk, vol 1 No. 2)

Nilai religius yang terdapat dalam sebuah karya sastra sangan penting karena menanamkan nilai-nilai kebaikan (agama) kepada pembaca, sehingga akan membentuk karakter yang sesuai dengan syariat yang berlaku dalam agamanya.

Salah satu karya sastra yang mengandung nilai religius yaitu novel. Novel merupakan bentuk karya sastra yang sekaligus disebut fiksi pada suatu novel, pengarang bebas dalam mengungkapkan tentang segala aspek hehidupan yang ingin diangkat menjadi sebuah cerita yang mengandung nilai nilai kehidupan yang dapat dijadikan contoh teladan bagi pembaca. (Nurgiantoro, 2013:12;Fauzan dkk, Vol.2 No.1 : Februari 2017)

Dengan melihat arti penting dan pengertian sastra terdapat bukti bahwa karya sastra dapat memberikan solusi untuk dunia pendidikan. Baik untuk penanaman akhlak (dasar religiusnya) maupun pengetahuan intelektualnya. Hal ini akan memberikan warna yang berbeda dengan mata pelajaran yang lan.

Pembelajaran sastra merupakan suatu pembelajaran untuk mengapresiasi sebuah suatu karya meliputi; puisi, prosa dan drama. Menurut Hidayat (2009) secara mekanisme, pembelajaran sastra di sekolah dapat mencapai tiga pokok kemampuan belajar, yaitu pada kemampuan afektif, kemampuan kognitif, dan kemampuan psikomotorik. Kemampuan afektif adalah kemampuan dasar manusia yang berkaitan dengan emosional seseorang. Kemampuan kognitif adalah kemampuan yang dimiliki oleh manusia berdasarkan pikiran. Kemampuan psikomotorik adalah kemampuan mengatur sisi kejiwaan untuk bertahan terhadap berbagai persoalan. Ketiga kemampuan tersebut secara serempak dapat ditemukan dalam pengajaran sastra.

Salah satu materi pembelajaran sastra yang terdapat dalam silabus bahasa Indonesia dan buku pegangan peserta didik bahasa Indonesia adalah novel. Novel yang dipelajari pada kelas XII dengan kompetensi dasar 3.9 yaitu menganalisis isi dan kebahasaan novel. Pada sub materi unsur ekstrinsik yang terdapat pada novel.

Berdasarkan kompetensi dasar 3.9 materi analisis isi teks novel, peserta didik dapat menelaah nilai-nilai religius pada novel yang dibaca.dalam pelaksanaan pembelajaran sastra di dalam kelas memerlukan strategi yang teppat agar siswa dapat belajar dengan baik dan memahami apa yang dipelajarinya. Dengan demikian, berdasarkan pemaparan tersebut peneliti mencari novel yang memiliki keterkitan dengan aspek nilai religius

sehingga mudah dipahami serta dibuatkan Rencana Pelaksanaan Pembelajaraanya pada tingkat SMA.

Berkaitan dengan beberapa hal di atas peneliti mengkaji novel Ranah 3 Warna karya Ahmad Fuadi, novel ini merupa 20 trilogi Negeri 5 menara yang diterbi 1 pada tahun 2011. Peneliti memilih novel ini untuk dianalisis karena melihat kesesuaian cerita dengan aspek nilai religius yang menjadi kajian bahan untuk pembelajaran sastra di tingkat SMA. Selain itu, karena berdasarkan pertimbangan terhadap pembelajaran di sekolah yaitu berdasarkan silabus, isi novel, dan nilai-nilai yang ada didalamnya sesuai untuk pembelajaran di sekolah. Novel Ranah 3 Warna karya Ahmad Fuadi akan dianalisis berdasarkan nilai religius yang akan dilakukan oleh peneliti kemudian hasil analisis dijadikan sebahan bahan pembuatan Rencana Pelaksanaan Pembelajaran sastra kelas XII SMA Negeri 1 Cikidang.

Tujuan penelitian ini yaitu menganalisis nilai religius dalam novel Ranah 3 Warna karya Ahmad Fuadi untuk dijadikan sebagai Rencana Pelaksanaan Pembelajaran sastra di kelas XII SMA Negeri 1 Cikidang.Sedangkan manfaat dari 


\section{ANALISIS NILAI RELIGIUS DALAM NOVEL RANAH 3 WARNA KARYA AHMAD FUADI DAN RRP KELAS XII}

penelitian ini adalah dapat memudahkan guru dalam memberikan materi pembelajaran sastra dengan Rencana Pelaksanaan Pembelajaran.

\section{METODE PENELITIAN}

Metode penelitian yang digunakan pada penelitian ini adalah metode penelitian kualitatif. Subjek pada penelitian ini adalah Rencana Pelaksanaan Pembelajaran sastra kelas XII SMA Negeri 1 Cikidang Nilai religius dalam novel Ranah 3 Warna karya Ahmad Fuadi. Novel tersebuta kemudain dibaca dan dianalisis nilai-nilai religiud yang mencakup Hubungan manusia dengan Tuihan-Nya, hubungan manusia dengan dirinya sendiri, hubungan manusia denga manusia, dan hubungan manusia dengan alam. Kemudian hasil analisis selesai dijadikan sebagai bahan pembuatan Rencana Pelaksanaan Pembelajaran satra kelas XII SMA Negeri 1 Cikidang.

Teknik pengumpulan data yang digunakan oleh peneliti adalah analisis isi, yaitu membahas dan mengkaji isi novel Ranah 3 Warna karya Ahmad Fuadi.. Adapun dalam penelitian ini, teknik analisis data yang digunakan meliputi pertama, Data-data yang dipilh hanya data yang berkaitan dengan masalah yang dianalisis, yaitu nilai-nilai religius dalam novel Ranah 3 Warna karya Ahmad kedua, Data-data yang dianalisis

sehingga diperoleh deskripsi mengenai nilai-nilai religius dalam novel Ranah 3 Warna karya dan ketiga, Setelah data disajikan, langkah selanjutnya yaitu penarikan kesimpulan menganai hasil dari data yang diperoleh sejak penelitian dimulai.

Prosedur penelitian yang akan dilakukan peneliri meliputi 1) tahap persiapan penelitian, tahap pelaksanaan peneltian, tahap pengolahan data penelitian. Didalam tahap persiapan pelaksanaan terdiri dari pemilihan novel yang sesuai dengan aspek yang diteliti, yakni novel Ranah 3 Warna karya Ahmad Fuadi dan tahap pembuatan instrumen penelitian yang digunakan oleh peneliti berupa kartu pencatat hasil analisis data. Selanjutnya dalam tahap pelaksanaan penelitian yaitu Pemaparan hasil analisis peneliti mengenai nilai religius dalam novel Ranah 3 Warna karya Ahmad Fuadi dan tahap pengolahan data penelitian Pada tahap ini data yang telah dikumpulkan dilapangan dianalisis peneliti untuk mendapatkan hasil dari penelitian.

\section{HASIL PENELITIAN}

Berdasarkan hasil penelitian mengenai analisis nilai religius dalam novel Ranah 3 Warna karya Ahmad Fuadi dan
Rencana Pelaksanaan Pembelajaranta di kelas XII SMA Negeri 1 Cikidang.

Analisis Nilai Religius dalam novel Ranah 3 Warna karya Ahmad Fuadi.

Pertama pada pemaparan analisis Nilai Religius dalam novel Ranah 3 Warna karya Ahmad Fuadi terdapat beberapa aspek yang meliputi; Hubungan manusia dengan Tuhan, hubungan manusia dengan dirinya sendiri, hubungan manusia dengan manusia dan hubungan manusi dengan lingkungan Alam. Berikut di bawah pemaparan hasil analisis terhadap nilai religius dalam novel Ranah 3 Warna karya Ahmad Fuadi.

\section{Hubungan manusia dengan Tuhan}

Hubungan manusia dengan Tuhan adalah hubungan vertikal yang menghubungkan perasaan manusia dengan TuhanNya.Wujud nilai religi hubungan manusia dengan Tuhan pada novel Ranah 3 Warna Karya Ahmad Fuadi adalah hubungan tokoh-tokoh dalam novel ini dengan Tuhan. Hubungan tersebut terbagi kedalam beberapa aspek diataranya; beriman, beribadah, bersyukur, membaca al-quran, sedekah, berdoa dan dzikir. Hasil penelitian aspek hubungan manusia dengan Tuhan dalam novel Ranah 3 Warna karya Ahmad Fuadi diatanya sebagai berikut.

1) Beriman

Penulis novel Ahmad Fuadi menghadirkan tokoh-tokoh dalam novelnya percaya kepada Tuhan Yang Maha Esa dan patuh terhadap perintah-Nya. Tokoh

Alif yang merupakan tokoh utama selalu diceritakan patuh terhadap perintah Tuhan sebagai wujud adanya nilai religius dengan indikator beriman kepada Tuhan yang dibuktikan dengan beberapa kutipan sebagai berikut :

“ Aku ingin membuktikan kepada mereka semua,bukan mereka yang menentukan nasibku, tapi diriku dan Tuhan."(Fuadi, 2011:8).

Berdasarkan kutipan di atas terlihat bahwa Alif percaya terhadap takdir yang ditentukan oleh sang pencipta yakni Allah swt, dia yakin bahwa setiap nasib seseorang bukan ditentukan oleh orang lain, tapi ditentukan oleh diri sendiri dan Tuhan.

"kalau aku sudah bingung dengan terlalu capek menghadapi segala tekanan hidup, aku praktikan nasihat kiai Rais, yaitu siapa saja yang mewakilkan urusannya kepada Tuhan, maka Dia akan mencukupkan semua kebutuhan kita." (Fuadi, 2011:35).

Berdasarkan kutipan di atas dapat dilihat bahwa Alif meyakinkan segala urusan kepada Tuhan, Allah semesta alam. Dengan cara seperti itu dia akan merasa tenang dan berkecukupan dalam menjalankan kehidupanya.

2) Beribadah 


\section{Wandi Setiawan, Tanti Agustiani, David Setiadi \\ ANALISIS NILAI RELIGIUS DALAM NOVEL RANAH 3 WARNA KARYA AHMAD FUADI DAN RRP KELAS XII}

Beribadah merupakan kewajiban bagi setiap umat Islam, sebagaimana perintah Allah ketika menciptakan manusia yaitu untuk beribadah kepadaNya. Dalam novel ini beberapa tokoh sangat patuh terhadap perintah Allah dalam hal ini yaitu selalu menjalankan perintahNya. Hal ini terbukti dari kutipan di bawah ini.

“ Nak, sudah wa'ang patuhi perintah Amak untuk sekolah agama, kini pergilah menuntut ilmu sesuai keinginanmu. Niatkanlah untuk ibadah, Insya Allah selalu dimudahkanNya." (Fuadi, 2011:41).

Berdasarkan kutipan di atas, dapat dilihat bahwa orang tua dari tokoh utama Alif memberikan nasihat kepada anaknya Alif untuk selalu beribadah kepada Allah. Ini membuktikan bahwa kutipan tersebut termasuk kedalam indikator beribadah kepada Allah.

"tapi, satu hal yang kau tak boleh lupa. Dalam rezeki kau itu ada hak orang lain. Walau sedikit, setiap honor itu kau potong dulu. Sisihkan buat amal, kalau perlu kalu antar sendir ke panti asuhan" "Iya Bang' jawabku pendek. Pikiranku melayang jauh ke masa aku di Pondok Madani. betapa seringnya Kiai Rais mengingatkan kami untuk mencintai anak yatim." (Fuadi, 2011:155).

Berdasarkan kutipan di atas terlihat bahwa Alif diberi nasihat oleh seorang tokoh yang berperan sebagai pengajarnya dalam dunia menulis berita, dia mengingatkan Alif untuk berbagi rezeki dengan orang lain, ini membuktikan bahwa terdapat nilai religius indikator beribadah karena berbagi rezeki

merupakan salah satu dari sikap seorang umat dalam beribadah kepada Tuhan yang Maha Esa.

3) Bersyukur

Bersyukur merupakan suatu ungkapan terimakasih terhadap apa yang telah kita dapatkan dalam kehidupan ini. Di dalam Al-Quran, kata syukur dengan kata nikmat disejajarkan oleh Allah.Nikmat yang diberikan oleh Allah patut kita syukuri sesuai dengan kemampuan kita.

"Beralaskan koran pengumuman, aku sujud syukur untuk keajaiban ini keajaiban tekad dan usah, keajaiban restu orangtua, keajaiban doa. Di sebelahku ayah juga sujud lama sekali." (Fuadi, 2011:30).

Kutipan di atas menunjukan tokoh utama yang mengungkapkan rasa syukur kepada Allah dengan cara besujud, hal itu merupakan perwujudan dari indikator bersyukur terhadap apa yang telah Allah berikan. Selain itu terdapat juga beberapa kutipan dibawah ini yang menunjukan rasa syukur.

Berdasarkan kutipan diatas dapat diperlihatkan wujud dari rasa syukur yang merupakan bagian dari aspek religius hubungan manusia dengan Tuhan. Sebagai manusia sudah seharusnya kita mensyukuri terhadap apa yang telah kita terima dan rasakan dalam keidupan kita, sesungguhnya dengan bersyukur kita akan merasakan ketenangan dalam menjalankan kehidupan.

4) Membaca Al-quran

Membaca Alquran merupakan ibadah yang utama. Ini adalah salah satu kelebihannya dari semua jenis buku dan bacaan yang lain. Baru sampai taraf membaca saja, Allah telah memberikan pahala yang banyak. Untuk satu hurufnya diganjar dengan 1 kebaikan dan dilipatkan menjadi 10 kebaikan. Sehubungan dengan ini, Rasulullah Saw. bersabda: "Abdullah bin Mas'ud radhiyallahu 'anhu berkata: "Rasulullah shallallahu 'alaihi wasallam bersabda: "Siapa yang membaca satu huruf dari Al Quran maka baginya satu

kebaikan dengan bacaan tersebut, satu kebaikan dilipatkan menjadi 10 kebaikan semisalnya dan aku tidak mengatakan a Jl satu huruf akan tetapi Alif satu huruf, Laam satu huruf dan Miim satu huruf." (HR. Tirmidzi dan dishahihkan di dalam kitab Shahih Al Jami', no. 6469). Pada novel Ranah 3 warna karya Ahamd Fuadi, kegiatan mebaca alquran terlihat pada kutipan dibawah ini.

"Diujung dipan beralaskan seprai putih ini tergeletak sebuah alquran kecil. Kata Amak kebiasaan Ayah akhir-akhir ini adalah membaca alquran sambil tidur, selain membaca artikel yang ditulis berulangulang kali." (Fuadi, 2011:92).

Berdasarkan kutipan di atas terlihat bahwa dengan membaca Al-Quran selain mendekatkan diri kepada Allah dan mendamaikan hati. Al-quran merupakan kitab pedoman bagi umat islam, membacanya merupakan salah satu perintah Allah yang harus dijalankan. Dari kutipan di atas dapat disimpulkan bahwa Ayahanda dari tokoh utama Alif sering mengisi harinya dengan membaca ayat-ayat suci Alquran, dan selalu mengisi harinya dengan ibadah.

5) Sedekah

Sedekah merupakan perilaku terpuji yang begitu disukai Allah SWT dan begitu dianjurkan bagi yang mempunyai rezeki lebih. Harta yang dimiliki sebagiannya adalah hak orang-orang yang tidak mampu, maka harus mengeluarkan hak mereka agar harta kita menjadi bersih. Dengan bersedekah akan membersihkan harta-harta kita.

"Tapi satu hal yang kau tak boleh lupa. Dalam rezeki kau itu ada hak orang lain. Walau sedikit, setiap honor itu kau potong dulu. Sisihkan buat amal, kalau perlu kau antar sendiri ke panti asuhan" "Iya 


\section{Wandi Setiawan, Tanti Agustiani, David Setiadi \\ ANALISIS NILAI RELIGIUS DALAM NOVEL RANAH 3 WARNA KARYA AHMAD FUADI DAN RRP KELAS XII}

bang, "jawabku pendek. Pikiranku melayang jauh ke masa aku di pondok madani. betapa seringnya Kiai Rais mengingatkan kami untuk mencintai anak yatim." (Fuadi, 2011:155).

Kutipan di atas menggambarkan bahwa terdapat nilai religius dalam aspek bersedekah yang merupakan bagian dari hubungan antara manusia dengan Tuhan dalam hal ini beribadah, tokoh utama Alif yang sudah belajar mandiri dan mendapatkan rezekinya dengan cara menulis diingatkan oleh seseorang yang berperan sebagai pelatihnya dalam menulis untuk menyisihkan sebagian dri rezeki yang didapatkan Alif untuk disdekahkan kepada yang berhak. Tentu saja Alif yang selalu berperilaku baik mematuhinya ditambah dia teringat dengan pepatah gurunya dulu waktu menjadi santri di Pondok Madani.

6) Bedo'a dan Dzikir

Berdoa kepada Allah merupakan cara manusia dalam meminta pertolongan dari Allah. Ketika kita sedang dalam kesulitan dalam masalah apapun maka mintalah pada Allah. Jika anak kita sedang mencari ilmu, mintakan pula doa untuk kelancaran dan kemudahannya dalam berpikir. Sebab, Allah sangat senang saat hamba-Nya berdoa. Allah pun akan merespon doa yang kita tengadahkan.

Sementara Zikir memiliki arti merupakan ibadah hati dan lisan yang tidak mengenal batasan waktu. Bahkan, Allah SWT menyifati ulil albab adalah mereka yang senantiasa menyebut Rabb-nya, baik dalam keadaan berdiri, duduk, bahkan juga berbaring. Oleh karenanya, zikir bukan hanya ibadah yang bersifat lisaniyah (ucapan), melainkan juga qalbiyah (hati).

"Nasihat singkat itu ditutup Ayah dengan doa bersama untuk perantauanku. Aku benamkan wajahku ke kedua telapak tangan dan aku bisikkan 'amin' yang bergetar panjang. Doaku untuk mengobati waswas di hati, semoga kuliahku tidak putus ditengah jalan karena ekonomi keluarga kami yang pas pasan." (Fuadi, 2011:41).

Keluarga dari tokoh utama pada novel Ranah 3 Warna yang diceritakan merupakan keluarga yang taat beragama, dibuktikan dengan kutipan di atas, pada saat Alif akan berangkat memulai kehidupannya di perantauan sebagai mahasiswa, segenap keluarga berdoa untuk kelancaranya di perantauan dalam mencari ilmu, itu membuktikan bahwa terdapat nilai religius pada indikator berdoa kepada Allah dalam setiap menjalankan kehidupan.

Hubungan antara Manusia dengan diri sendiri

Pada indikator hubungan manusia dengan diri sendiri terdapat enam subindikator yaitu sabar, mandiri, ikhlas, pantang menyerah, muhasabah, dan sikap bijak. Hasil penelitian dalam novel Ranah 3 Warna karya Ahmad Fuadi terdapat enam subindikator yaitu sebagai berikut.

1) Sabar

Dalam perjalanan hidup setiap manusia tak akan luput dari cobaan yang berupa kesenangan, kenikmatan atau penderitaan. Dalam menghadapi semua itu yang diperlukan manusia adalah dengan cara bersabar terhadap ujian yang dihadapi.

Sabar yang dicerminkan dalam novel Ranah 3 Warna karya Ahmad Fuadi terdapat pada saat Alif mendapatkan beberapa cobaan hidup yang dapat dibuktikan dari kutipan dibawah ini .

"Aku mencoba bersabar ketikan mengantar jasad Ayah sampai ke lahat. Aku sabar ketika harus ikut ujian tanpa persiapan memadai. Aku sabar ketika kembali ke Bandung sebagai anak yatim." (Fuadi, 2011:129).

Berdasarkan kutipan di atas, terlihat bahwa Alif selalu sabar dalam menghadapi semua cobaan yang dia dapatkan dalam perjalanan hidupnya.

2) Mandiri

Mandiri merupakan salah satu sikap yang perlu manusia miliki. Berusaha untuk mendapatkan apa yang kita inginkan dan apa yang kita butuhkan merupakan sikap mandiri, jangan karena merasa kita tidak bisa dan selalu menyusahkan orangtua maupun orang lain. Sikap mandiri dalam novel Ranah 3 Warna karya Ahmad Fuadi adalah ketika Alif yang kembali ke Bandung sepeninggalan ayahnya sehingga harus berusaha untuk hidup mandiri dan mencari biaya tambahan sendiri dan berhenti meminta kepada Ibunya.Hal tersebut terlihat pada kutipan berikut ini.

"Mungkin sudah waktunya aku disapih, berhenti meminta uang ke Amak. Aku genggam foto keluarga erat-erat, sampai hampir remuk. Aku berjanji pada diri

sendiri akan membiayai diri sendiri selama di bandung." (Fuadi, 2011:101).

Berdasarkan kutipan diatas terlihat bahwa Alif bertekad dalam hatinya untuk mencoba hidup mandiri tanpa harus selalu meminta pada ibunya orang lain, ketika hidup di Bandung.

Berdasarkan kutipan yang telah dipaparkan di atas dapat disimpulakan bahwa sikap mandiri selalu kita miliki. Kemandirian dalam menghadapi segala hal yang terjadi dalam kehidupan kita, mencari solusi bagaimana cara kita menyelesaikan berbagai masalah. Dengan kemandirian dapat mendewasakan kita serta menjadikan kita manusia yang lebih baik.

3) Ikhlas

Ikhlas merupakan sebuah kata yang mudah diucapkan namun terkadang tidak 


\section{ANALISIS NILAI RELIGIUS DALAM NOVEL RANAH 3 WARNA KARYA AHMAD FUADI DAN RRP KELAS XII}

mudah untuk dilakukan. Banyak sekali pribahasa yang mengatakan bahwa kita harus selalu menjalankan sesuatu dengan keikhlasan seperti bekerja dengan ikhlas supaya hidup ini lebih tenang dan bahagia. Cerminan sikap ikhlas pada novel Ranah 3 Warna karya Ahmad Fuadi terdapat pada kutipan berikut.

"Akhirnya aku memilih untuk ikhlas saja, walaupun diperlakukan dengan keras." (Fuadi, 2011:76).

Kutipan di atas menujukan sikap ikhlas dari tokok utama Alif yang sedang dibimbing dan dilatih dengan keras untuk bisa menjadi seorang penulis yang profesional, terbukti ketika dia menjalakannya dengan keikhlasan akhirnya tulisan yang dihasilkan bisa diterbitkan di majalah kampusnya.

Berdasarkan pemaparan kutipan di atas maka dapat disimpulkan bahwa dengan ikhlas kita akan merasakan kehidupan yang tenang meskipun cukup sulit namun setelahnya kita akan mendapatkan timbal balik dari keikhlasan itu.

4) Pantang menyerah

Pantang menyerah adalah suatu sikap dalam berupaya keras untuk terus berusaha agar mencapai sesuatu. Pantang menyerah dilakukan seseorang ketika mempunyai tujuan tertentu agar mendapatkan apa yang diinginkan. Sikap pantang menyerah dalam novel Ranah 3 Warna karya Ahmad Fuadi adalah sikap yang dimiliki Alif saat ia berusaha untuk mengejar penyetaraan ijazah SMA sebagai syarat untuk bisa melanjutkan pendidikan ke jenjang yang lebih tinggi. Hal itu terbukti dari kutipan di bawah ini.

"Siap, Yah. Jadi ambo bertekad akan memaksmalkan usaha persis seperti Denmark. Membalikan penilaian seтиa orang yang memandang sebelah mata" (Fuadi, 2011:25).

Kutipan di atas menunjukan sikap Alif yang pantang meyerah dan berusaha lebih keras lagi untuk belajar dalam mempersiapankan ujian penyetaraan Ijazah SMA, Alif menyamakan usahanya dengan salah satu tim sepakbola yang pada zaman itu sedang berlaga pada suatu turnamen tingkat dunia namun selalu diremehkan lawannya, tetapi dibuktikan dengan kerja tim itu berhasih keluar sebagai juara, begitupun dengan usaha yang Alif lakukan, ditengah ejekan temannya Randai sehingga dia berusaha untuk membuktikan dan mencapai keinginnanya untuk melajutkan ke pendidikan yang lebih tinggi

5) Muhasabah (mawas diri)

Mawas diri dalam setiap jengkal kehidupan yang dilalui sungguh penting, karena dengan muhasabah kita sebagai manusia dapat mengintrospeksi diri untuk menjadi manusia yang lebih baik. Seperti yang dilakukan Alif yang mengintropeksi hidupnya yang penuh dengan ujian, dan mencoba memperbaiki diri.Hal tersebut dapat dilihat dalam kutipan berikut ini.

"Kerja ini jauh lebih berat dari yang aku bayangkan. Kenapa engkau beri aku cobaan seperti ini ya Tuhan? Untunglah setiap keluh ku makin menjadi-jadi dan dramatis, aku ingat lagi Mang Udin, tukang sepatu satu tangan di Pasar Simpang itu. Aku tibatiba malu besar karena telah meratapi nasib dengan cengang." (Fuadi, 2011:115)

Berdasarkan kutipan di atas dapat terlihat bahwa mengintrospeksi diri atau bermuhasabah sangatlah baik bagi kehidupan yang lebih baik. kutipan di atas menunjukkan bahwa Alif merasa lebih beruntung jika dibandingkan dingan orang lain yang jauh lebih berat ujian kehidupannya, Mang Udin sebagai perbandingan dirinya karena mang Udin terlahir dengan kekurangan sementara Alif yang terlahir dengan sempurna alahkah malunya jika harus merengek meratapi hidupnya.

6) Sikap Bijak

Sikap bijak adalah suatu tindakan yang disertai dengan pemikiran matang sehingga apa yang kita lakukan merupakan suatu hal yang benar. Sikap bijak yang terdapat dalam novel Ranah 3 Warna Karya Ahmad Fuadi adalah sikap Alif terhadap Randai temannya yang selalu bertindak melemahkan dan mengejek Alif namun dia berusaha menghadapinya dengan bersikap baik terhadap temannya. Hal itu dibuktikan dalam kutipan berikut ini.

"Sebelum kembali ke bandung tempo hari, Randai berkali-kali mengajak aku menginap di kamarnya di Dago, "Sampai wa'ang mendapatkan tempat kos sendir" katanya sambil menulis alamat lengkap di selembar kertas. Sebenarnya aku masih kesal dengan kata katanya di pingggir danau dulu. Aku tidak akan lupa pertanyaanya yang meremehkan diriku. Tapi setelah aku pikirpikir lagi, Randai tetap kawanku, bahkan kawan terdekatku. sebaiknya kekesalan ini harus aku buang. apalagi sekarang aku sudah berhasil membuktikan bahwa keraguannya salah." (Fuadi, 2011:43).

Berdasarkan kutipan di atas dapat terlihat bahwa sikap bijak Alif dalam memutuskan tindakan untuk tidak membalas terhadap apa yang dilakukan oleh temannya itu, dan lebih memilih untuk bersikap baik dan membuktikannya dengan hasil yang telah dicapainya yaitu bisa kuliah di Bandung.

\section{Hubungan antara Manusia dengan Manusia}

Hubungan manusia dengan manusia adalah hubungan yang menghubungkan 


\section{Wandi Setiawan, Tanti Agustiani, David Setiadi \\ ANALISIS NILAI RELIGIUS DALAM NOVEL RANAH 3 WARNA KARYA AHMAD FUADI DAN RRP KELAS XII}

perasaan manusia dengan manusia.Wujud nilai religius hubungan manusia dengan manusia pada novel Ranah 3 Warna karya Ahmad Fuadi adalah hubungan tokoh terhadap tokoh lainnya.

Pada indikator hubungan manusia dengan manusia terdapat empat subindikator yaitu Tolong menolong, keakraban, bermanfaat bagi orang lain, dan husnuzan. Hasil penelitian dalam novel Ranah 3 Warna karya Ahmad Fuadi terdapat empat subindikator yaitu sebagai berikut.

Tolong menolong

Tolong-menolong yang terdapat dalam novel Ranah 3 Warna Karya Ahmad Fuadi merupakan tolong-menolong antara Alif dan temannya Randai, ketika Randai membatu Alif untuk tinggal bersamanya saat di Bandung. Hal itu terbukti dari kutipan di bawah ini.

"Tapi aden tidak enak menumpang terus bersama wa'ang" "Lif, kita kan kawan, tinggal saja dulu disini sampaia ketemu kos yang pas" (Fuadi, 2011:62).

Berdasarkan kutipan di atas dapat terlihat bahwa sikap tolong menolong tumbuh di dalam diri Randai sebagai teman Alif

yang membantunya tinggal di kosan saat kuliah di Bandung. Sebagai sesama manusia sudah selayaknya kita saling tolongmenolong.

\section{Keakraban}

Keakraban pada novel Ranah 3 Warna Karya Ahmad Fuadi dapat dilihat dari sikap tokoh Alif dengan teman barunya di Bandung saat bercengkrama dan menjalin keakraban sebagai teman yang baru kenal di masa ospek Universitas. Hal itu terbukti dari kutipan di bawah ini.

"Berjam-jam kami mengobrol hilir-mudik. Topik yang paling kami sukai adalah saat Memet maju mendamaikan dua pihak yang bertikai sambil bertelanjang dada. Kami lalu terpingkal-pinhkal sampai sakit perut setiap mengulang cerita ini. Jadi, kalaulah ada manfaat ospek bagiku, yaitu mengakrabkan aku dengan kawan-kawan satu angkata." (Fuadi, 2011:59).

Berdasarkan kutipan di atas dapat dilihat bahwa wujud keakraban terjalin dari tokoh-tokoh yang diceritakan dalam novel yang tidak lama berkenalan dan mulai menjalin keakraban sebagai hubungan yang baik antar sesama manusia.

Bermanfaat untuk orang lain

Sebagai manusia sudah selayaknya kita bisa bermanfaat bagi orang lain, dalam novel Ranah 3 Warna karya Ahman Fuadi wujud sebagai manusia yang bermanfaat bagi orang lain terlihat pada saat Alif mengabdikan dirinya kepada orang lain sebagai pengajar Bahasa Arab di masjid kampus ITB. Hal tersebut terbukti dari kutipan dibawah ini.

"Aku juga meluangkan waktu 2 jam seminggu untuk mengajar Bahasa Arab di Masjid Salman ITB. Tentu saja gratis. Ini caraku mengabdikan ilmu yang aku dapat dari Pondok Madani kepada Masyarakat. Nasihat Kiai Rais berdengung-dengung di kepalaku. "Jadilah seperti anjuran Nabi, khairunnas anfauhum linnas, sebaikbaiknya manusia adalah manusia yang meberi manfaat bagi orang lain." (Fuadi, 2011:65).

Berdasarkan kutipan di atas terlihat bahwa Alif menjadikan dirinya untuk bisa bermanfaat bagi orang lain dengan cara mengajarkan Bahasa Arab bagi masyarakat sekitar. Ketika kita bisa bermanfaat bagi orang lain maka kita akan mendapatkan syafaat dari Allah swt.

Husnudzon

Husnuzan merupakan salah satu sikap yang harus dimiliki oleh seorang muslim, yakni dalam artian jelasnya sikap berprasangka baik dan tidak berburuk sangka terhadap orang lain, Membiasakan berperilaku husnuzan perlu kita lakukan terhadap sesama muslim atau lainnya selama mereka tidak mengusik dan mendzalimi kita. Hal ini dapat dilihat pada kutipan dibawah ini.

"Rupanya ibu Sonia itu susah ditaklukan. Sambil berjalan pulang aku mencoba menghibur diri. Kalau mengikuti nasihat Kiai Rais aku telah menunaikan seтиa tugasku untuk mencapai keberhasilan. Yaitu niat lurus dan ikhlas, usaha keras, doa khusyuk. Tinggal aku genapi saja dengan huznuzhan, berprasangka baik." (Fuadi, 2011:208).

Berdasarkan kutipan di atas dapat terlihat dari sikap Alif sebagai tokoh utama yang selalu mengamalkan ajaran di pesantren yang salah satunya bebaik sangka terhadap orang lain, ketika Alif sedang melaksanakan seleksi untuk menjadi kandidat sebagai mahasiswa pilhan yang akan sebagai pertukaran mahasiwa.

\section{Hubungan Manusia dengan alam sekitar} Nilai peribadatan juga terjalin antara manusia dengan alam sekitarnya. Allah menciptakan semesta alam ini. sebelum manusia sebagai wujud adanya Allah Swt. Dalam novel Ranah 3 Warna karya Ahmad Fuadi digambarkan kepedulian tokoh Alif terhadap hewan ciptaan Allah swt. Hal itu dapat dibuktikan dari kutipan dibawah ini.

"Iseng, aku melemparkan sepotong roti dengan takut-takut, satu tupai mendekati roti itu dan menggondolnya delam sarangnya di sebuah pohon ek." (Fuadi, 2011:446). 


\section{Wandi Setiawan, Tanti Agustiani, David Setiadi \\ ANALISIS NILAI RELIGIUS DALAM NOVEL RANAH 3 WARNA KARYA AHMAD FUADI DAN RRP KELAS XII}

Berdasarkan kutipan di atas dapat terlihat wujud hubungan manusia dengan alam sekitar dalam hal ini Alif peduli terhadap hewan penghunii pohon dan memberikan sedikit makanannya untk berbagi. Sebagaimana kita sebagai manusia harus berbuat baik terhadap apa-apa yang diciptakan Allah dimuka bumi ini. Begitupun dengan kutipan dibawah ini.

"Di lokasi-lokasi ini populasi hewan sudah melebihi daya tampung sebuah kawasan alamiah.kalau populasi terlalu padat bisa menjadi hama. Selain itu saya juga mengajarkan pemburu untuk menghormati alam. Semua mahluk hidup punya ruh. jadi kalau berburu pastikan prosesnya cepat dan tidak menyakiti hewan buruan kita." (Fuadi, 2011:345).

Kutipan di atas menggambarkan sikap peduli terhadap lingkungan alam dengan selalu menghargai dan memelihara kelangsungan habitat dan menjaga alam agar tetap dalam keadaan stabil dan baik.

\section{Rencana Pelaksanaan Pembelajaran (RPP)}

Hasil penelitian nilai-nilai religius dalam novel Ranah 3 Warna karya Ahmad Fuadi. Dapat diimplikasikan pada pembelajaran Bahasa Indonesia di SMA kelas XII pada KD3.9 menganalisis isi dan kebahasaan novel. Impilkasi ini dapat dilihat dalam bentuk bahan ajar pada bagian kegiatan inti dalam rencana pelaksanaan pembelajarab (RPP) dengan alokasi waktu 2x45 menit Model pembelajaran yang digunakan dalam pembelajaran yaitu Cooperative Integrated Reading And Composition (CIRC).

Tujuan pembelajaran mengacu pada indikator yang memuat aspek pengetahuan, sikap, dan keterampilan.Siswa dituntut untuk mengerti bahwa kualitas dirinya diukur dan menjadi terampil.Siswa diharapkan mengerti unsur pembangun sastra dari sisi luar yang dalam hal ini mencakup nilai religius pada novel Ranah 3 Warna karya Ahmad Fuadi.

Kegiatan peserta didik yang terdapt salam Rencana Pelaksanaan Pembelajaran (RPP) yaitu menganalisis nilai-nilai religius (Hubungan manusia dengan Tuhan, Hubungan Manusia dengan Diri Sendiri, Hubungan Manusia dengan Manusia. Dan Hubungan Manusia dengan Lingkungan Alam). Serta mempresentasikan hasil analisi pada nilai-nilai religius dalam novel Ranah 3 Warna karya Ahmad Fuadi.

\section{SIMPULAN}

Berdasarkan hasil tentang analisis nilai-nilai religius dalam novel Ranah 3 Warna karya Ahmad Fuadi dapat disimpulkan hal-hal sebagai berikut :
Hasil penelitian menunjukan bahwa dalam novel Ranah 3 Warna karya Ahmad Fuadi mengandung nilai-nilai religius dengan berbagau indikator . pada indikator nilai religius Hubungan Manusia dengan Tuhan terdapat beberapa subindikator nilai religius yaitu Beriman kepada Allah, Beribadah, Bersyukur, Membaca Alquran, Sedekah, Berdoa, dan Berdzikir. Nilai religius pada Indikator Hubungan Manusia dengan Diri Sendiri yairu; Sabar, Mandiri, Ikhlas, Pantang menyerah, Muhasabah. Dan Bersikap bijak. Nilai religius pada indicator hubungan manusia dengan manusia yaitu; Tolong menolong, Keakraban, Bermanfaat untuk orang lain, dan husnudzon. Adapun nilai religius pada indicator Hubungan Manusia dengan Alam sekitar berhubungan dengan bagaimana cara manusia bersikap terhadap lingkungan sekitar dalam hal ini seperti tumbuhan, hewan serta semua yang diciptakan oleh Allah swt. Hasil penelitian dijadikan sebagai Rencana Pelaksanaan Pembelajaran (RPP) pada kelas XII pada Kompetensi Dasar (KD) 3.9 Menganalisis isi dan kebahasaan novel.

\section{DAFTAR PUSTAKA}

Fuadi, $\begin{gathered}\text { Ahmad. 2011. } \\ \text { Warna.Jakarta } \\ \text { Putaka Utama. }\end{gathered}$

Jauhari, Heri. 2010. Cara Memahami Nilai Religius dalam Pendekatan reader's response.Bandung : Arfino Raya.

Lathief, Supaat I. 2008.Sastra: Eksistensialisme-Mistisme

Religius. Lamongan ; Pustaka Ilalang.

Mangunwijaya,Y.B. 1988. Sastra dan Religiositas. Yogyakarta: Sinar Harapan.

Nova dkk. 2017 Nilai Religius dalam Novel Bulan Terbelah di langit Amerika karya Hanum Salsabiela Rais dan Rangga Almahendra. Jawa Barat : Universitas Galuh.

Nurgiantoro, Burhan. 2013. Teori Pengajaran Fiksi. Yogjakarta: Gadjah Mada University Press.

Sukirno. 2013. Belajar Cepat Menulis Kreatif Berbasis Kuantum. Yogyakarta: Pustaka Pelajar.

Wellek, Warren. 2016. Teori Kesusastraan. Jakarta : Gramedia. 